This item was submitted to Loughborough's Research Repository by the author.

Items in Figshare are protected by copyright, with all rights reserved, unless otherwise indicated.

\title{
Climate change and slope stability in the UK: challenges and approaches
}

PLEASE CITE THE PUBLISHED VERSION

http://dx.doi.org/10.1144/1470-9236/09-036

PUBLISHER

(c) Geological Society of London

VERSION

AM (Accepted Manuscript)

LICENCE

CC BY-NC-ND 4.0

REPOSITORY RECORD

Dijkstra, Tom, and Neil Dixon. 2019. "Climate Change and Slope Stability in the UK: Challenges and Approaches”. figshare. https://hdl.handle.net/2134/11441. 
This item was submitted to Loughborough's Institutional Repository (https://dspace.lboro.ac.uk/) by the author and is made available under the following Creative Commons Licence conditions.

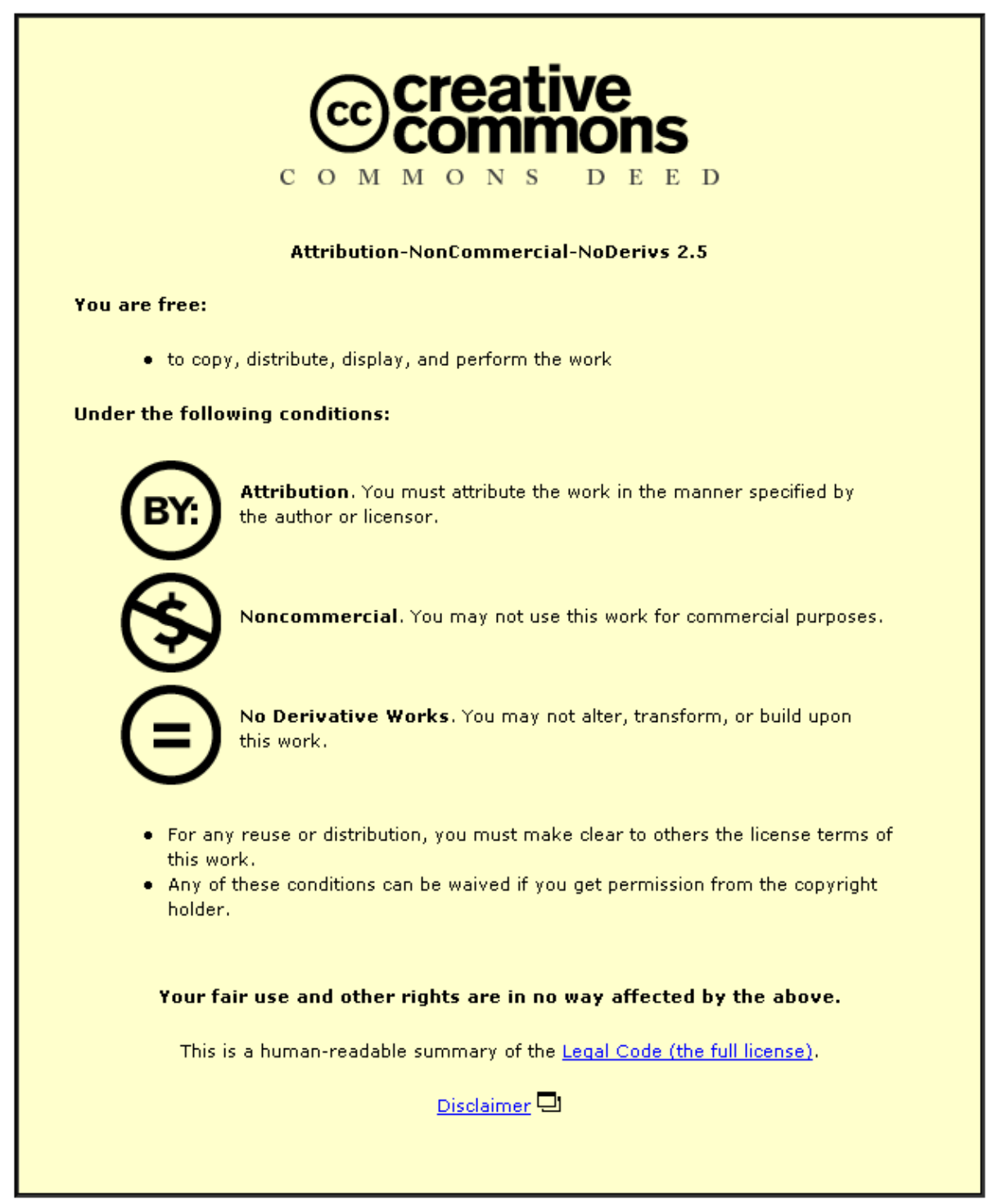

For the full text of this licence, please go to: http://creativecommons.org/licenses/by-nc-nd/2.5/ 
Dijkstra, T.A. \& Dixon, N. (2010). Climate change and slope stability: Challenges and approaches. Quarterly Journal of Engineering Geology and Hydrogeology, 43, 4, 371-385.

\title{
Climate change and slope stability in the UK: Challenges and approaches
}

\author{
Dijkstra, T.A. and N. Dixon \\ Department of Civil and Building Engineering, Loughborough University, \\ Loughborough \\ LE11 3TU, UK \\ t.a.dijkstra@lboro.ac.uk
}

\begin{abstract}
It is now widely accepted that climate change is occurring and that this will affect the processes and parameters that determine the stability of slopes. There remains, however, significant uncertainty in forecasting these changes in the long-term. This issue was addressed in a series of workshops, organised as part of a UK-wide network on CLimate Impact Forecasting For Slopes (CLIFFS). The major outcomes from the workshop discussions provide a focus for the modelling environment relevant to long term forecasting of slope stability that include better definition of material properties, improved understanding of processes (notably an upgrading from the site-specific to the regional scale) and more effective communication to achieve synergies of understanding in this multi-disciplinary research environment.
\end{abstract}

Warming of the global climate due to anthropogenic influences is well documented and widely accepted (e.g. Hulme et al. 2002; Stainforth et al. 2007; Jenkins et al. 2009; Collins 2007). Ongoing climate change is now 'reasonably foreseeable' (see e.g. Firth and Colley 2006) and any uncertainty associated with the forecasts can no longer be used as an excuse to ignore the problem (e.g. Grossman 2003; Perroy 2006; Metcalf et al. 2009; Willows and Connell 2003). Failure to take account of the potential adverse effects of climate change on the stability of landscapes will carry additional financial risk (ABI 2009, Stern 2007), for example when inappropriate design, operation and maintenance strategies in undulating landscapes and earthworks continue to be applied (Dijkstra and Dixon 2007). Adaptation to forecasted changes in climate conditions is now key and this requires upgrading the knowledge base and slope instability modelling capability (Derbyshire et al. 2001; Dixon et al. 2007, 2008; Glendinning et al. 2008)).

This realisation has led to increasing pressures to take action and gain the necessary knowledge that would enable a more effective adaptation to the potentially adverse consequences of climate change, impacting natural and constructed (engineered) slopes and affecting both first-time and reactivated failures. This has been supported by targeted funding from the Engineering and Physical Sciences Research Council (EPSRC) in the UK for research into the implications of climate change (Building 
Dijkstra, T.A. \& Dixon, N. (2010). Climate change and slope stability: Challenges and approaches. Quarterly Journal of Engineering Geology and Hydrogeology, 43, 4, 371-385.

Knowledge for a Changing Climate (BKCC), Sustaining Knowledge for a Changing Climate (SKCC) and now Adaptation and Resilience to a Changing Climate (ARCC) programmes - see for example UKCIP/EPSRC 2003; Walsh et al. 2007).

Links between climate and slope stability have been researched as part of these programmes, but it was recognised that many relevant research efforts exist in many different disciplines and research communities. Communication between these different groups and engagement with stakeholders has traditionally been poor. To address this issue and to enhance the potential for synergy through collaborative research, the EPSRC in the UK provided start-up funding for a network - CLIFFS (CLimate Impact Forecasting For Slopes; Dijkstra and Dixon 2007; Dixon et al. 2007). Thematic workshops took place in 2006/07 and a dissemination symposium was held in February 2008. These activities allowed sharing of expertise and ideas, and were used to formulate research questions, to keep stakeholders informed, obtain guidance from them on priorities and address specific issues raised by the end user community. An important focus of the discussions was the need to quantify the effects of climate change on pore pressure responses and resultant rates of deformation. It is clear that there are still fundamental questions that remain to be answered. For example, how will climate change (in particular effective rainfall) affect slope stability? How well do geotechnical specialists understand pore pressures in complex geological environments - what happens when slides move? How do pore pressure variations lead to changes in landslide movement? To what extent do changes in basic assumptions lead to changes in outcomes - e.g. is summer drying and resultant formation of shrinkage cracks enabling more efficient wetting up of potential slip surfaces during winter storms? This paper briefly introduces the impacts of slope instability and the context of climate change forecasting. This is followed by a discussion of the current status of the forecasting capability with respect to responses of slope stability to climate change drivers. This discussion is an attempt to capture the outcomes of the workshops and symposium organised as part of the CLIFFS network, It is hoped that the issues raised will serve as an opportunity to engage in further discussions and research efforts that ultimately should lead to better slope instability process models and a more successful integration of these models with climate change forecasts (in particular UKCP09).

\section{Impact of unstable slopes in the UK}

The stability of engineered slopes (such as embankments and cuttings associated with infrastructure networks) cannot be analysed effectively without considering the local geologies that contribute to the materials comprising these slopes, nor can the local geomorphological processes and landforms be ignored (see e.g. Phipps 2003). A preliminary analysis of the spatial distribution of unstable slopes indicates that some $10 \%$ of Great Britain can be classified as having a moderate to significant landslide hazard potential (Dixon et al. 2007; Jackson 2004). The dominant source materials generating unstable slopes include the London Clay Formation, Lias Group and Gault Formation. Further important drivers include natural slope evolution and morphology and the effects of engineered interventions in both cuttings and embankments. More than 7\% the main transport network (motorways, railway lines and A-roads) is located in areas with moderate to significant 
Dijkstra, T.A. \& Dixon, N. (2010). Climate change and slope stability: Challenges and approaches. Quarterly Journal of Engineering Geology and Hydrogeology, 43, 4, 371-385.

landslide potential. This potential for landsliding can be mobilised during periods of, for example, intensive rainfall. This response of slope systems to extremes of precipitation is well recorded. The extremely wet winter conditions of $2000-2001$ and 2004 caused widespread slope failures in both natural and constructed slopes in SE England, Wales and Scotland (Dixon et al. 2008, Glendinning et al. 2008, Winter et al. 2007).

The potential financial impact is demonstrated through the following examples. Although the Highways Agency does not have fixed cost structures for the closure of motorways it is estimated that costs would be of the order of $£ 5,000$ to $£ 10,000$ pounds per hour per lane of motorway (Lords Hansard, 2007). Network Rail spends upwards of $£ 80$ million per annum on earthwork related activities (RAIB 2008). The distribution of housing stock in the UK in relation to land with a significant potential for landsliding suggests that some 365,000 properties are at risk (Culshaw, 2008 pers. comm.)

Models used to determine landslide potential, such as the one underpinning the landslide hazard potential map generated by the British Geological Survey (BGS), are based on relatively simple Boolean operators combining information of a landslide database and geological/topographical information. It is recognised, by among others the BGS, that this has limitations, prohibiting, for example, sophisticated assessments of the potential impacts driven by a changing climate (Dixon et al. 2007).

\section{Predicted climate change}

The Inter-governmental Panel on Climate Change (IPCC, 2001) concluded that "most of the warming observed over the last 50 years is likely to be attributable to human activities". Changes in climate will be driven by greenhouse gas emissions of our recent past and future trends of emissions of greenhouse gases and other pollutants. Carbon dioxide levels in the atmosphere provide a good indicator of a changing climate and atmospheric concentrations have risen by over $30 \%$ since the industrial revolution. Global average temperatures rose by $0.6^{\circ} \mathrm{C}$ during the 20th century and, in terms of average annual temperatures, 2007 was the joint 10th warmest year on record and 9 of the 12 warmest years since 1659 have occurred since 1990 (Westaway 2008). A brief summary of the recent climate trends is presented in Table 1.

The United Kingdom Climate Impact Programme (UKCIP) 2002 climate change scenarios describe .expected climate changes over the 21st century for four different greenhouse gas emissions scenarios and three time slices centred on the 2020s, 2050s and 2080s. The emission scenarios are driven by assumptions regarding the directions of development of population, economies, technology and societies. Due to the lag-effect there is no discernable difference between scenarios in terms of average global temperatures up to the 2040s. Beyond this, deviations between the various scenarios exist, but the relative likelihood of these paths is unknown at present (Figure 1).

Headline messages from UKCIP02 include increasing average annual temperatures with important regional and seasonal variations, wetter winters and drier summers (leading to potentially large 
Dijkstra, T.A. \& Dixon, N. (2010). Climate change and slope stability: Challenges and approaches. Quarterly Journal of Engineering Geology and Hydrogeology, 43, 4, 371-385.

reductions in end-of-summer soil moisture conditions), and more frequent heavy winter downpours (Table 2; Hulme et al., 2002).

Feedback from users of the climate data highlighted a need for improvements in climate modelling to provide greater spatial detail, and consideration and quantification of associated uncertainties. In response, UKCP09 has been developed to provide a new set of climate projections. It was launched in 2009 (Murphy et al. 2009; Jones et al. 2009). and An explanation of the context together with an analysis of recent trends (1971-2000 versus 1961-1990) is published by Jenkins et al. (2009). UKCP09 addresses the uncertainties of earlier projections by using a multi-model ensemble; running one model over and over with different parameterisations, and including runs from other models (see e.g. Collins, 2007; Stainforth 2007; Pope et al. 2007 and New et al. 2007). It uses three predetermined emissions scenarios (Low, Medium and High Emissions) and the resultant probabilistic projections are targeted 30-year "decades" from 2020s to 2080s (the 'baseline' is maintained as the period from 1961-1990). Projections are available at 25km resolution for the whole of UK, averaged over each month, seasonally and annually (Jenkins et al. 2009; Murphy et al. 2009).

To provide further detail, a weather generator has been development that builds on the EARWIG weather generator developed at the Universities of Newcastle and East Anglia (e.g. Kilsby et al. 2007; Jones et al. 2009). Typical daily precipitation values for 1961-1990 are used as input and users are able to turn these into statistically equivalent daily values for some time in the future, using transformation functions in the form of rainfall characteristics and UKCP09 monthly climate change projections (Wilks and Wilby 1999). This is relevant to a resolution of $5 \mathrm{~km}$. In addition, it is also possible to analyse the output by applying user-defined daily weather thresholds.

Access to UKCP09 information is through a user interface that allows users to create customised image products such as maps, probabilistic plots, plume diagrams and scatter graphs, customised numerical products such as GIS format files and sampled model output. These probabilistic forecasts of future climate form a promising development in the quality of the climate data for input into slope stability models (Jenkins et al. 2009; Murphy et al. 2009; see also www.ukcip.org.uk for further up-todate information). However, the slope stability modelling communities still need to develop their capabilities further to reach a status where the full potential on offer from the climate modellers can be used effectively in the broad assessment (i.e. not sporadic and site specific) of long-term slope stability development.

\section{Forecasting climate impacts on slopes}

\section{Modelling reality}

Experience derived from training, observations and experimentation provides a qualitative understanding of the processes and parameters that assists in drawing up a perceptual model of the links between climate change and slope stability. Further, targeted procedures are then put into place to achieve a degree of quantification of key components of this model (for example as part of the site investigation process). Representation of this perception of reality is naturally limited firstly by our 
Dijkstra, T.A. \& Dixon, N. (2010). Climate change and slope stability: Challenges and approaches. Quarterly Journal of Engineering Geology and Hydrogeology, 43, 4, 371-385.

understanding of the complexity of the system (natural variability or aleatory uncertainty) and secondly by our capability to transform this into a conceptual or working model where all elements are reliably represented by equations and quantifiable parameters within acceptable levels of uncertainty or variability (epistemic uncertainty). This transform of reality into simulation model only generates outcomes that are approximately realistic (see, for example, Beven 2002 for an in depth philosophical background).

The stability of slopes, whether natural or constructed, is the consequence of sets of processes and parameters interacting in a complex hierarchy of systems. In the short term, these systems can be regarded to be in a steady state - i.e. the set of processes and parameters determining slope stability are relatively stable. Presently, most design and management of slopes is carried out on the basis of this assumption, possibly enhanced by using an arbitrary contingency if the site is particularly sensitive and long-term stability is questionable. These relatively crude assessments provide results that, through experience, can be translated into appropriate designs, and operation and management strategies for both natural and engineered slopes.

This may be acceptable for slopes that have limited potential impact on human activities at or near the site. However, for many slopes that affect the Built Environment in general, and infrastructure earthworks in particular, the design life of these assets is some 60 to 120 years and thus covers a period over which climate conditions are forecast to change significantly.

These traditional models have a very limited capability to incorporate climate information (often only through applying some additional factor of safety) and are therefore not suited to address long term assessments of slope stability variations in any detail. They preclude, for example, assessments of the potential importance of changes in both nature and intensity of processes driving instability, such as preferential pathways for water ingress due to desiccation crack development or incremental strains delivered by ratcheting-type movements of surface slopes in plastic clays.

It is plausible that, during the design life of a slope, the magnitude of change in climate controls (mainly expressed in terms of changes in precipitation, temperature and sea level rise) will be such that processes contributing to the stability of slopes will change significantly. Recurrence intervals between key critical events may shorten, recovery times of slopes (e.g. involving slope drainage) may not be fully available and landscape systems may enter a stage of severe instability leading to an onset of an entirely new equilibrium to which slopes will want to adjust (Figure 2).

Forecasting landslide occurrence is not only determined by changes in environmental conditions, such as those driven by climate change. Other mechanisms influencing the stability of slopes may also form an important driving mechanism. Anthropogenic changes in slope conditions as provided by, e.g., agricultural activities and infrastructure/urban development, and also natural processes (e.g. earthquakes) can give rise to major phases of slope modification. In the UK, earthquakes are not of a sufficient magnitude to drive such changes. However, human impact on the landscape is extensive and manifested through widespread construction, infrastructural developments and land use changes throughout history. Such modifications of the environmental conditions influencing landscape 
Dijkstra, T.A. \& Dixon, N. (2010). Climate change and slope stability: Challenges and approaches. Quarterly Journal of Engineering Geology and Hydrogeology, 43, 4, 371-385.

sensitivity occur at a rate that is much faster than climate change. Therefore, even where relatively good records exist, as in certain parts of the UK, it is often very difficult to separate an historical climate signal from an anthropogenic signal in the temporal and spatial patterns of landslide occurrences (see e.g. Wasowski 1998; Bromhead and Ibsen, 2006; and Ibsen and Brunsden 1996). As a consequence of the poor historical signal, there exists a dependency on an improved understanding of the process based models to further develop a slope stability forecasting capability. It is possible to design different simulation models that provide results in line with expectations and existing data sets (the concept of equifinality; Beven 2002). Some of these models will be behavioural models that provide reliable results with varying sets of input conditions and non-behavioural models that do not and can therefore be rejected. Narrowing down the range of possible model options could follow the generalised likelihood uncertainty estimation (GLUE) approach of Beven and Binley (1992). However, there is a danger that models will be rejected, because they represent some unexpected, unrecognised (but 'realistic') outcome. Rejection criteria must therefore be applied sensitively to longterm temporal mapping of the activity of slopes where controlling conditions change significantly from those affecting prior performance. Ranking of likelihood of the models should also take into account the greater opportunities for flexibility that some models offer over others.

\section{Historical versus process-based model (PBM) performance}

Many approaches to contextualise slope models are based on their past performance (using an historical model; see, for example, Ibsen and Brunsden 1996; Dikau et al., 1996; Guzzetti et al. 1999). This process assists with the determination of factors contributing to the past performance of these slopes (their 'what, where and when'), if sufficient data sets are available. However, major system components such as temperature and precipitation are now subject to a rate of change that deviates significantly from those of the recent past (pre-1900). Extrapolation from past performance is therefore of questionable value. Carrara et al. (2003) demonstrated that a geomorphological model (basically a process-based model analysing slope stability within morphologically meaningful units) has the potential to outperform an historical model in the correct prediction of slope stability status. However, where good historical datasets are available and where frequency of landsliding falls well within a human timescale, historical models provide important benefits. Therefore, a case can be made for joint use of these approaches to enhance capture of overall stability and identification of most frequently reactivated sites (Carrara et al. 2003; Glade, 2001).

Changes in antecedent pore pressures and alteration of trigger event magnitudes will lead to a change in the frequency, distribution and mode of landsliding, not just as a consequence of combined changes in the triggers (e.g. precipitation events) and conditioning or preparatory factors (e.g. the antecedent groundwater conditions), but also in response to concomitant changes in other controlling variables such as land-use, vegetation cover and soil water chemistry. It is therefore required to more closely look at the thresholds that govern the potentially dynamic (even meta-stable) responses of landscapes to changing external driving factors (see, for example, Bracken and Wainwright 2006 for a recent address of relevant terminology). This includes slope systems that, due to recovery periods 
Dijkstra, T.A. \& Dixon, N. (2010). Climate change and slope stability: Challenges and approaches. Quarterly Journal of Engineering Geology and Hydrogeology, 43, 4, 371-385.

exceeding recurrence intervals of critical threshold events, may reach a state where no equilibrium applies. It is important to take stock of the scales at which these events and processes are being considered, both in a spatial and in a temporal scale. By and large, the processes will apply to the local scale, extending to regions (such as transport corridors) and will be relevant to timescales of approximately 100 years.

It must therefore be recognised that steady state assumptions do not apply (cf. Derbyshire et al. 2001) and that our understanding of the changing nature of processes determining the stability of slopes must be improved to enable more effective forecasting for the projected lifespan of these slopes.

The assessment of slope stability variations with time therefore requires careful analysis of the various levels in the hierarchy of systems that serve the overall stability simulation model. As the effective stress variations driving slope stability are the consequence of the soil's interactions with water, it is logical to group systems accordingly. These systems should include a climate process system (for evaluation of the water balance), a land use/vegetation system (to quantify transfer of water at the near surface), a regional hydro-geological system (enabling a refinement of the local water balance) and a multi-layered soil system that can cope with variations in soil and soil water (Morgenstern and Martin 2008; van Beek 2002). The system components (process, form) can change over time and the simulation models need to be designed flexibly so that these changes can be accommodated.

Further development of dynamic physically-based models (PBMs) should be promoted as part of a wider set of assessments available to forecast behaviour at unstable sites (e.g. van Beek 2002; Brooks et al. 2004; Malet et al. 2005). This must include enhanced capabilities to incorporate probabilistic assessments into the slope models (see for example the work done by Phoon and Kulhanny 1999a, 1999b; Lacasse and Nadim 1997 and others).

The main advantage of PBMs for hydrology and slope stability analyses is that hydrological processes are explicitly considered and simulated hydrology (including suction and variable ground water levels) is used as input for the pore pressure conditions in the slope stability analysis.

However, understanding of internal hydrology of mass movements is still limited even in very densely instrumented sites. The Super-Sauze site (France) is a good case in point (Malet et al. 2005). The ways in which water can enter the lower (critical) zone of the slide mass during a storm with a potentially critical intensity is dependent upon, for example, the availability of fissures, which are, in turn, dependent upon antecedent rainfall and moisture contents available in the upper body of the slide. Therefore, a better understanding of how rainfall patterns influence the build-up of critical soil moisture levels, capable of leading to failure, is needed. The relevant PBM developed by Malet et al. (2005) comprises a very strong hydrological core model that assesses landslide stability (generating factors of safety) as a function of transient conditions (hydrology) dependent upon initial conditions, slope geometry and material properties, and climatic controls (time series and extremes). However, this study highlights the drawbacks associated with broader application of these types of models 
Dijkstra, T.A. \& Dixon, N. (2010). Climate change and slope stability: Challenges and approaches. Quarterly Journal of Engineering Geology and Hydrogeology, 43, 4, 371-385.

which depend heavily on the requirement of a high degree of detail in input data (which is not often available). There are also problems to contend with in terms of parameterisation and process selections (and interaction) that are not yet fully understood. These will lead to errors in the model and, due to the way the models are constructed; this can lead to large error propagation limiting the potential usefulness of these models for forecasting purposes.

One potential way of improving the performance of PBMs is to combine these with Monte Carlo simulations. Evaluation of these model runs using comparisons with observed occurrences of slope instability can then result in the establishment of critical thresholds that, in turn, can assist with the forecasting of slope behaviour under a range of climate scenarios.

In addition to trying to achieve an acceptable level of representing the real world it is also essential to design models that are robust (or flexible) enabling an evaluation of model outcomes of unforeseen conditions (for example, non-historical weather sequences generated by the climate modellers - the unexpected may happen and models need to be able to incorporate these). In the current framework of slope modelling capability, important further research is required to achieve this capability. There are still many processes that are poorly understood and many parameters that are poorly calibrated. The following section briefly highlights some of the key issues that need addressing.

\section{Subjective assessments and scenario building - a way forward?}

Slope stability forecasting simulation models continue to suffer from poor parameter specification generally the result of scarce measurements. Spatial and temporal variations in these parameters further complicate the picture, not just in natural slopes, but also in engineered slopes where variations in compactive effort, for example, can result in important consequences for the mobilisation of strains. Expert opinion on parameter specification is therefore often divided and this prohibits representation of parameters through unique probability distributions (Hall et al. 2006). Nevertheless, a case can be made for subjective (or contextual) probability assessments by individuals and consensus assessments by groups of experts to provide a way forward where little hard evidence exists (e.g. following the elicitation process detailed in Garthwaite et al. 2005; Fookes 1997). These assessments could then be used to achieve a better understanding of comprehensive sets of processes affecting the simulation of slope stability (reducing skewed approaches that are determined by the specific subject area background of small sets of researchers) and it has the potential to provide initial sets of parameter probability distributions that can be updated as further information becomes available (e.g. Lee and Moore 2007).

This consensus approach may also prove useful in a context of building up plausible narratives of how the stability of slopes may be affected by climate driven processes over the next 60 to 100 years. These narratives could evolve into construction of (sets of) formalised slope stability scenarios, in a similar fashion as the process engaged, several decades ago, by the climate modelling communities for designing scenarios of greenhouse gas emissions. A climate change forecasting context is already developed. At all other levels (geo-hydrology, vegetation, soil parameter variability, etc.) there is still a large amount of further research required. For the moment, the capability appears limited to using probability functions of input parameters to assess likelihood of failure. These provide some 
Dijkstra, T.A. \& Dixon, N. (2010). Climate change and slope stability: Challenges and approaches. Quarterly Journal of Engineering Geology and Hydrogeology, 43, 4, 371-385.

opportunity to model into the future, enabling a forecast approach that can include probability functions of variations over time such as climate change inputs into the slope model (Lacasse et al. 2004; Chowdury and Flentje 2002). It does not, however, address the issue of meta-stability of the systems and for this we need to develop relevant scenarios (Greeuw et al. 2000).

To produce slope stability scenarios needs the involvement of multi-disciplinary groups and these should outline how the various system components contributing to slope stability change over time. Once slope scenarios have been formalised, they can be used as a basis for further modelling, providing a guiding narrative and basic checklists of essential system components, key decision points and integration of a balanced set of parameters. Doing this within a formal framework will enable the research communities to contribute to simulations that are comprehensive and are not skewed towards a researcher's particular subject background.

\section{Characterising processes and parameters}

In homogeneous materials, transient pressure response rates are primarily determined by the balance between rainfall, soil thickness and diffusivity. Iverson (2000) provides a model to analyse this response for a potentially unstable slope to determine slope stability and post-failure displacement (Figure 3). However, variations in permeability due to spatial heterogeneity of density and occurrence of soil structure and (desiccation or stress release) cracks can strongly overshadow this relationship. Where bypass flow is important, meteorological detail required to obtain meaningful correlations with slope deformation may have to be scaled down to daily, or even hourly input quality (Van Asch et al. 1996, Van Asch et al.1999). Even if historical monitoring data is of sufficient quality to generate this level of detail, cases where this detail can be correlated with the exact timing of events are very rare. In addition, in many cases the initial pressure distributions are often unknown, reliable permeability data is scarce and in situ variability can be several orders of magnitude, particularly in natural slopes and older, engineered embankments (e.g. O'Brien 2007, Robinson 2008). This makes the characterisation of the response function and resultant transient pressure distribution challenging. The triggering of landslides occurs at a wide range of scales, from shallow to deep-seated failure surfaces, each warranting a specific hydrological model (Figure 4). Shallow landslides, particularly those that show regular re-activation, form an important category of slope movement for the determination of critical climate thresholds and require detailed modelling of effective rainfall required to initiate movement. The lag time for significant increases in pore pressure to reach deeper failure surfaces makes the establishment of critical climate thresholds more complex. Several events could be required to trigger instability, and therefore issues such as antecedent rainfall or, more importantly, antecedent soil moisture contents and pore pressures need to be determined. Knowledge of precipitation alone is not sufficient. The effects of incoming radiation, driving the evaporative losses, must be considered also. In accentuated terrain, topographical effects (e.g. slope exposure and heat gain, channelling of surface flows, etc.) form additional important variables affecting this system (van Beek 2002; van Asch et al. 2007). 
Dijkstra, T.A. \& Dixon, N. (2010). Climate change and slope stability: Challenges and approaches. Quarterly Journal of Engineering Geology and Hydrogeology, 43, 4, 371-385.

High permeabilities, provided by coarse soils or interconnected end-of-summer desiccation cracks in plastic clays, may give rise to shallow translational slides controlled by spatially continuous hydrological jumps at a critical depth (see e.g. Brooks et al. 2004). In the case of desiccated clay soils, the typical rise in water levels is some eight times the depth of rainfall. This may become a more widespread issue as climate change induces deeper desiccation crack development during drier summers potentially resulting in greater magnitudes of pore pressure variations (see e.g. Bracegirdle et al. 2007, Vaughan et al. 2002).

The stability of high permeability soils is determined by, among others, antecedent soil water content and retention curve, stratigraphy, hydraulic conductivity, and the presence of macro-pores. These conditions in the vadose zone are particularly important in determining the rates of shear strength reduction when winter precipitation wets up soils with high suctions generated by warmer summer conditions, a situation potentially affected by forecasted increases in seasonality (Winter et al. 2007; Iverson and Major 1987; Hanenberg 1991; Kayane and Kaihotsu 1988; Johnson and Sitar 1990; Torres et al. 1998; Simoni et al. 2004).

Antecedent precipitation is often identified as an essential component in the triggering of slope failures and, dependent upon slope conditions may require several days (Reid, 1994; Matsukura, 1996; Van Asch et al., 1996) to several months (Moore et al. 2007a, 2007b; Dixon and Brooks 2007; Iverson and Major, 1987) before triggering rainfall has an effect. Shallow failures are driven by small variations in the mobilisation of shear strength, such that a $10 \mathrm{kPa}$ pore pressure change could lead to a 30\% change in shear strength (O'Brien, 2007). It is clear that in these shallow zones, the response to changes in precipitation may have rapid and important consequences. In turn, this also emphasises how much detail is required to incorporate into the slope models so that adequate assessments of slope stability can be achieved. The response of deep failures in cuttings to triggering rainfall trends is often poor due to very slow pore pressure adjustments. However, in cases of enhanced bypass flow, progression of elevated pore pressures may be speeded up leading to a more rapid response (e.g. Loughbrickland; Clarke et al. 2005; Hughes et al. 2007).

Changes in vegetation and land use, in response to changing climate conditions or affected by short term adjustments to extreme weather events, can have important consequences for the stability of slopes. These changes carry the potential to overshadow the effects of rainfall in determining the thresholds for spatial and temporal distribution of slope instability (e.g. Wasowski, 1998; Ibsen and Brunsden, 1996; Glade, 2003; Sidle et al., 2006). In particular where there is a risk of activation of shallow slip surfaces, it has been shown that changes in land use and vegetation affect the likelihood of failure. Field studies linked to physical models incorporated into a GIS-based framework have contributed substantially to an improved understanding of these relationships (e.g. Van Beek, 2002; van Beek and van Asch, 2004; Cammeraat et al., 2005)). For deep-seated landslides the influence of land-use and vegetation changes is less well understood. Extrapolation of regionally specific rule sets linking land use/vegetation to slope stability is limited by substantial uncertainty of the generic processes underlying these linkages. Further research is therefore required to establish reliable 
Dijkstra, T.A. \& Dixon, N. (2010). Climate change and slope stability: Challenges and approaches. Quarterly Journal of Engineering Geology and Hydrogeology, 43, 4, 371-385.

models that can underpin management strategies that would limit the potential negative effect of vegetation/land use on slope stability (Dixon et al., 2008).

In addition to these traditionally recognised failure scenarios, climate change may also lead to other mechanisms of failure becoming (more) prevalent. One example is that of a ratcheting type near surface behaviour driven by increasing differences in soil moisture status between end-of-summer and winter conditions (Take and Bolton 2004).

\section{Traditional modelling and Long term forecasting}

\section{Use of traditional stability models}

Traditionally, deterministic models are used to interpret the state of a slope. Soil variability, both in terms of stratification and in terms of characteristic parameters, is determined using relatively crude methodologies, is translated into parameters that can be inputted into the models and is assumed to be much more homogeneous than local conditions warrant. The models further only provide rough approximations of stresses and strains and associated factors of safety. As a consequence, these methods are only capable of providing indicative information on the stability of a slope and require the use of engineering judgement to produce a workable hypothesis of how a particular slope can be managed. As long as steady state conditions are assumed, this approach has been demonstrated to provide acceptable results. However, if significant uncertainty exists in the characterisation of material parameters, their geological relevance and their variation over time, the value of deterministic models rapidly diminishes (e.g. Zhao 2008). For example, critical slip surfaces may not necessarily be those with the lowest conventional factor of safety, but are determined by a combination of mean factor of safety and uncertainty (Lacasse et al. 2004). It is therefore imperative that greater use is made of probabilistic assessments of slope stability, and that capabilities in using statistical variation of input properties are enhanced. These reliability model approaches do not reduce the amount of uncertainty over those implicitly included in the deterministic models. They do, however, use this in a more transparent way and provide a better basis for engineering judgement to take place.

\section{Modelling landscape sensitivity}

Landscapes can be viewed as evolving over time to reach a condition of (marginal) stability. Anywhere along this evolutionary path, short periods of time may be determined where steady state conditions can be assumed to apply. The stability of slopes can then be assessed on the basis of resilience and sensitivity of the system at that moment in time (often expressed in equilibrium terms as the balance between driving and resisting forces along a potential slip surface). However, when external controls, such as climate and land use, are subject to important changes over the period over which these stability assessments apply, it is possible that both intrinsic and extrinsic thresholds will be exceeded that, in turn, manifest large changes in stability conditions - a dynamic meta-stable equilibrium applies. Active slope instability is thus a highly visible outcome of landscapes that adjust to changes in a complex system. Being able to quantify these thresholds and when these are likely to 
Dijkstra, T.A. \& Dixon, N. (2010). Climate change and slope stability: Challenges and approaches. Quarterly Journal of Engineering Geology and Hydrogeology, 43, 4, 371-385.

be exceeded will be of great practical value (an old and well-established issue, but one still being aspired to; see e.g. Schumm and Lichty 1965; Schumm 1979; Brunsden and Thornes 1979).

Triggering of slope deformation may generate form responses that significantly alter future threshold transgressions - failed slopes are likely to have a different susceptibility to subsequent event input due to their changed morphology and material characteristics. In many cases, a meta-stable dynamic system needs to be applied to enable more realistic outcomes compared to those predicted on the basis of steady state assumptions of trigger and form response. The importance of including these more complex responses has already been illustrated by studies such as those of van Asch et al. (1996), van Asch et al. (1999) van Beek (2002), Bromhead et al. (1998), Collison et al. (2000), Buma (2000), Dehn et al. (2000).

For near surface slope instability, the distribution and magnitude of controlling pore water pressures are the direct and indirect consequences of climate change and will be most important. Examples of approaches to simulate these effects range from intensity-duration (I-D) threshold envelopes at relatively small scales, to large scale, site based analyses using fully-coupled hydrological-slope stability models (see for example O'Brien et al. 2004; Manning et al. 2008; Glendinning et al. 2006; Rouainia et al. 2009; Hughes et al. 2009). There are still many gaps in the quality of data and understanding of topography effects, soil properties, precipitation, hydrological properties and changing site conditions through time that limit the usefulness of these fully coupled models). Therefore, at present most practical value still appears to reside in the relatively simple models (see for example van Beek 2002; Casadei et al. 2003; Dikau and Schrott 1999; Fairbank and Jakeways 2006; Mclnnes, 2006).

The development of detailed digital topographical (and sometimes stratigraphical) site characterisations provides a useful platform to extend these studies in a GIS environment (Carrara and Pike 2008; Walstra et al. 2007a and 2007b). In rapidly changing environments, failure mechanisms may change, some sites may become higher risk areas and increased seasonality may introduce 'new' dominant processes contributing to failure. The conditions included in simulation models (e.g. Dixon and Brook, 2007; Schmidt and Glade, 2003) are only partially representations of the real world. This opinion is reinforced by Carrara and Pike (2008) who observe that forecasting the magnitude, location and timing of landslides is still a quest unfulfilled by current GIS practice. They conclude that there is a shift towards incorporating a range of quantitative approaches. However, it is yet too early to identify which direction is most promising. They also warn not to focus on validation, but rather to concentrate on evaluation of quantitative information since, according to Oreskes (1998), it is "not possible to demonstrate the predictive reliability of any model in a complex natural system in advance of its use".

\section{Research needs to improve forecasting capabilities}

The effects of climate change on slopes in the UK is, as yet, uncertain. Climate change may lead to a deterioration of slope stability and a plausible scenario illustrating this potential effect involves drier 
Dijkstra, T.A. \& Dixon, N. (2010). Climate change and slope stability: Challenges and approaches. Quarterly Journal of Engineering Geology and Hydrogeology, 43, 4, 371-385.

summers that are likely to lead to increasing deformation in plastic clays. In turn, heavy precipitation events, both as summer storm events and during wetter winters, could lead to bypass flow through desiccation crack systems so that effective stresses are rapidly reduced at critical slip surfaces and slope deformations result. However, it is also plausible that higher evapotranspiration could lead to a reduction in infiltration and more intense rainfall could lead to more run off, thus resulting in drier, more stable slopes. Until a comprehensive set of narratives is formulated it is only possible, at this stage, to conclude that as a consequence of these observations, failure mechanisms active in UK slopes are likely to change. Whether this will lead to a higher frequency and magnitude of reactivation of existing unstable slopes, or the initiation of slope movement at hitherto stable sites remains to be determined. Due to the episodic nature of slope stability events and a limited understanding of parameters and processes to which these events respond, current levels of uncertainty are so great that long-term forecasts are still of limited use to those responsible for the management of slopes. There is therefore an urgent need for further research to achieve a better understanding of:

- Soil parameters - spatial and temporal (including strain dependency) characterisation. Plasticity is generally well addressed, but characterisation of shear strength requires further work. Issues of variability and uncertainty for many geological strata and derived fills remain and there is a need to upgrade strategies for obtaining input parameters and their calibration/validation for use in slope assessments. This requires comprehensively characterised sites with long-term data sets (e.g. Smethurst et al., 2006; Clarke et al. 2005; Hughes et al. 2007; Glendinning et al. 2006). The development of longer term slope stability forecasts is now possible, even though there are still issues of data management to contend with (i.e. how to convert site specific data on a slope into useable regional scale information). Probabilistic approaches in geotechnical analysis are required to integrate with the probabilistic values of UKCP09 climate change scenarios.

- Determining site scale deviations from general characterisations. This includes a need to detect deviations from the general stress field in order to identify locally overstressed zones, "hidden defects" such as previous failures and granular pockets, variations in compaction and permeability contrasts, effects of drainage, etc. It also includes a need to raise awareness of the different scales at which parameter and process variations occur. For example, soil properties may require definition at the site scale, surface hydrology is determined on a (micro-) catchment basis, hydro-geology may need characterisation beyond surface basins, and climate will be influenced by even larger regional variations. Methodologies are required to effectively integrate information from these different scales.

- Characterisation of permeability, in particular near the surface, and the links with infiltration and hence pore pressure variations in the slopes. There is an urgent need for a fundamental understanding of the relationships between temporal and spatial pore pressures in complex geological environments and the link between these and slope movements. This requires the development of more robust techniques, and equipment, for temporal in-situ permeability measurement. Collation of historical datasets is needed to aid understanding of factors 
Dijkstra, T.A. \& Dixon, N. (2010). Climate change and slope stability: Challenges and approaches. Quarterly Journal of Engineering Geology and Hydrogeology, 43, 4, 371-385.

controlling pore pressure changes and considerable research is needed to test hypotheses in the field.

- The effect of vegetation - generally poorly addressed in site investigation and project development. The complex impact of trees on hydrology, and hence on temporal and spatial pore pressures, and their potential mechanical benefits also require further work. This should include the influence of different tree species in common clay types and the zones of influence of vegetation on the temporal magnitude and distribution of pore water pressures. Further work is needed to fully understand the effects of vegetation change on stability, in terms of soil type, permeability and type of vegetation.

- Key critical climate scenarios and the integration of these into a systems model. It is generally accepted that creating slope stability models based on static information such as fixed recharge boundary conditions calculated from past behaviour is no longer acceptable for the long-term forecasting of responses of slope systems to climate change. Model development needs to incorporate observed seasonal and short term behaviour of pore water pressures in slopes to create non-steady state systems that can then be simulated with sequences of future climate scenarios relevant to the long-term responses of slope systems. Once a better, formalised, set of scenarios of climate-vegetation-slope interactions has been developed, it is required to develop flexible models based on UKCP09 probabilistic outputs of climate change. In turn, this could then lead to the development of solutions for the optimum design and management of slopes. The probabilistic forecasts delivered as part of UKCP09 are an exceptional resource, but it is questionable whether the geotechnical community is ready to implement this data on a large scale into the modelling of long-term slope stability.

- Communicating the message effectively. Traditional deterministic models appear to have worked well thus far. However, a case is made that the community involved in addressing slope stability needs to put a greater focus on probabilistic approaches, particularly if longterm forecasts are to be achieved that are compatible with the best available science of climate change (e.g. UKCP09). If research produces forecasts that indicate change in slope stability, the underpinning science must be robust to inform slope managers how they could adapt their assessment and management strategies to ensure long term resilience. As stated in the introduction, communication is currently poor between the various groups that are actively involved in slope stability assessments. The activities of the CLIFFS network have addressed this to some extent. However, there is still some way to progress the effectiveness of communication of scientific developments to the wider public, including stakeholders such as infrastructure asset managers. Continuing the dialogue is therefore imperative to deliver the insights required to shape an environment that is as resilient as can be reasonably expected from the potential long term changes in slope stability as these are driven by climate change. 
Dijkstra, T.A. \& Dixon, N. (2010). Climate change and slope stability: Challenges and approaches. Quarterly Journal of Engineering Geology and Hydrogeology, 43, 4, 371-385.

\section{Summary}

It is clear that the predisposition of slopes to excessive deformation varies in a spatial context and is influenced by a range of variables forming part of a hierarchy of processes and parameters that are largely interdependent and respond at different time scales to the effects of climate change. It is feasible to group these variables into three distinct levels:

- material properties and processes - including shear strength, plasticity, permeability, unsaturated conditions, etc;

- $\quad$ site specific conditions - including stratigraphy and hydro-geology (e.g. bypass flow), vegetation cover, propensity for developing cracks, drainage provisions, topography (such as exposure, slope angle, micro-catchment), etc; and

- broad environmental context - variation in climate influence, changes in infrastructure network use, etc.

At each of these levels, uncertainties and limitations still exist that require further investigation through laboratory testing, field investigations and computer modelling. These uncertainties require quantification (and reduction), and the temporal and spatial variability at each level needs to be clearly defined. This would range from achieving a better understanding of relevant processes, via assessments of seasonal and inter-annual slope surface states (including crack depth, permeability and vegetation cover) to modifications of the hydro-geology driven by changes in the long-term precipitation-evapotranspiration balance. Coupled with additional information on the spatial and temporal changes in susceptibility this should result in improved analyses of long term stability forecasts of slope stability in a context of climate change. It must be realised that a successful outcome can only be realised through multi-disciplinary research and a continuing engagement between science-based and engineering-based approaches.

\section{Acknowledgements}

The CLIFFS network was supported by EPSRC grants (GR/T26856/01 and EP/F013299/1). Thanks are due to the many contributors to the CLIFFS workshops and the symposium, and in particular to the core members at the British Geotechnical Association (BGA), the British Geological Survey (BGS), British Waterways, CF Skanska, the Geotechnical Consulting Group (GCG), Halcrow, Highways Agency, Isle of Wight Council, Mott MacDonald, UKCIP, and researchers at the Universities of Birmingham, Bristol, Imperial College, Kingston, Loughborough, Newcastle, Nottingham Trent, Queen's Belfast and Southampton. The authors would also like to thank the reviewers for their constructive comments. 
Dijkstra, T.A. \& Dixon, N. (2010). Climate change and slope stability: Challenges and approaches. Quarterly Journal of Engineering Geology and Hydrogeology, 43, 4, 371-385.

\section{References}

$\mathrm{ABI}$ (Association of British Insurers) 2009. Preparing the UK for climate change - ABI's new adaptation strategy. January 2009, ABI, London, 5p.

Beven, K.J. 2002. Towards a coherent philosophy for modelling the environment. Proc. R. Soc. Lond. A, 458, 2465-2484

Beven, K.J. \& Binley, A.M. 1992. The future of distributed models: model calibration and uncertainty prediction. Hydrological processes, 6, 279-298

Beven, K.J. \& Freer, J. 2001. Equifinality, data assimilation, and uncertainty estimation in mechanistic modelling of complex environmental systems using the GLUE methodology. Journal of Hydrology, 249, $11-29$

Bracegirdle, A., Menkiti, C.O. \& Clark A.R. 2007. Climate change impacts on landslide mechanisms and hazard in southern UK. In: McInnes, RG, Jakeways, J, Fairbank, H and E Mathie (eds.) Landslides and climate change - challenges and solutions. Taylor Francis, p.259-267.

Bracken L. J. \& Wainwright, J. 2006. Geomorphological equilibrium: myth and metaphor? Transactions of the Institute of British Geographers, 31, 2, 167 - 178

Bromhead, E.N., Hopper, A.C. \& Ibsen M.L. 1998. Landslides in the Lower Greensand escarpment in south Kent. Bulletin of Engineering Geology and the Environment, 57, 2, 131-144

Bromhead, E.N. \& Ibsen, M.L. 2006. A review of landsliding and coastal erosion damage

to historic fortifications in South East England. Landslides. 3:341-347

Brooks, S.M., Crozier, M.J., Glade, T.W. \& Anderson M.W. 2004. Towards Establishing Climatic Thresholds for Slope Instability: Use of a Physically-based Combined Soil Hydrology-slope Stability Model. Pure Applied Geophysics. 161, 881-905

Brunsden, D. \& Thornes J. B. 1979. Landscape Sensitivity and Change. Transactions of the Institute of British Geographers, New Series, 4(4), 463-484.

Buma, J. 2000. Finding the most suitable slope stability model for the assessment of the impact of climate change on a landslide in SE France. Earth Surface Processes and Land-forms, 25, 565583.

Cammeraat, E. Van Beek, R, \& Kooijman, A. 2005. Vegetation succession and its consequences for slope stability in SE Spain. Plant and Soil, 278:135-147

Carrara, A., Crosta, G. \& Frattini, P. 2003. Geomorphological and historical data in assessing landslide hazard. Earth Surface Processes and Landforms, 28, 1125-1142. 
Dijkstra, T.A. \& Dixon, N. (2010). Climate change and slope stability: Challenges and approaches. Quarterly Journal of Engineering Geology and Hydrogeology, 43, 4, 371-385.

Carrara, A. \& Pike, R.J. 2008. GIS technology and models for assessing landslide hazard and risk. Geomorphology, 94, 257-260.

Casadei, M., W. E. Dietrich \& Miller N. L. 2003. Testing a model for predicting the timing and location of shallow landslide initiation in soil-mantled landscapes. Earth Surface Processes and Landforms 28, 925-950.

Chowdury, R.N. \& Flentje, P. 2002. Uncertainties in rainfall-induced landslide hazard. Quarterly Journal of Engineering Geology \& Hydrogeology, 35, 61-69

Clarke, G.R.T., Hughes, D.A.B., Barbour, S.L. \& Sivakumar V. 2005. Field Monitoring of a Deep Cutting in Glacial Till: Changes in Hydrogeology. GeoSask2005, the 58th Canadian Geotechnical Conference and 6th CGS \& IAH-CNC Joint Groundwater Specialty Conference, Saskatoon, Canada, September 18-21

Collins, M. 2007. Ensembles and probabilities: a new era in the prediction of climate change. Phil. Trans. R.Soc, 365, 1957-1970.

Collison, A., Wade, S., Griffiths J. \& Dehn M. 2000. Modelling the impact of predicted climate change on landslide frequency and magnitude in SE England. Engineering Geology, 55, 205-218.

Culshaw, M. 2008. Pers. Comm.. Communicating the risks arising from geohazards. Presentation to the CLIFFS climate change and slope instability symposium, Loughborough University, February 2008, available at cliffs.lboro.ac.uk.

Dehn, M., Burger G., Buma, J. \& Gasparetto P. 2000. Impact of climate change on slope stability using expanded down-scaling. Engineering Geology, 55, 193-204.

Derbyshire, E., Dijkstra, T.A. \& van Beek L.P.H. 2001. Forecasting medium to long-term slope stability in a context of progressive environmental change. In: Sassa, $\mathrm{K}$ (Ed.) Procs. UNESCO/IGCP Tokyo Symposium on landslide risk mitigation and protection of cultural and natural heritage. 221228

Dijkstra, T.A. \& Dixon N. 2007. Networking for the future - addressing climate change effects on slope stability. In: McInnes, RG, Jakeways, J, Fairbank, $\mathrm{H}$ and E Mathie, (eds.) Landslides and climate change - challenges and solutions. Taylor Francis, 275-280.

Dikau, R., Brunsden, D., Schrott, L., \& Ibsen, M.-L., 1996. Landslide recognition. Identification, movements and causes. Wiley, Chichester, England, 251 pp.

Dikau, R. \& Schrott, L. 1999. The temporal stability and activity of landslides in Europe with respect to climate change (TESLEC): main objectives and results. Geomorphology, 30, 1-12.

Dixon, N., Dijkstra, T.A. Forster, A. \& Connell R. 2007. Climate change impact forecasting for slopes (CLIFFS) in the built environment. IAEG conference 2006, Paper number 528. The Geological Society of London. 
Dijkstra, T.A. \& Dixon, N. (2010). Climate change and slope stability: Challenges and approaches. Quarterly Journal of Engineering Geology and Hydrogeology, 43, 4, 371-385.

Dixon, N. \& Brook E. 2007. Impact of Predicted Climate Change on Landslide Reactivation: Case Study of Mam Tor, UK. Landslides, 4, 2, pp.11 (CD)

Dixon, N., Dijkstra, T.A., Glendinning, S., Hughes, P.N., Hughes, D.A.B., Clarke, D., Smethurst, J., Powrie, W., Toll, D.G. \& Mendes J. 2008. Climate change and slope stability - improving our forecasting capabilities. Proceedings GeoEdmonton08 - 61st Canadian Geotechnical Conference and 9th Joint CGS/IAH-CNC Groundwater Conference. Edmonton September 2008.

Fairbank, H. \& Jakeways J. 2006. Mapping coastal evolution and risks in a changing climate - a training pack. Centre for the Coastal Environment, Isle of Wight Council. 45p.

Fookes, P.G. 1997. Geology for Engineers: the Geological Model, Prediction and Performance. Quarterly Journal of Engineering Geology \& Hydrogeology, 30, 293-424

Firth, J., \& Colley, M. 2006 The Adaptation Tipping Point: Are UK Businesses Climate Proof? Acclimatise and UKCIP, Oxford, 36p.

Garthwaite, P.H., Kadane, J.B. \& O'Hagan, A. 2005. Statistical methods for eliciting probability distributions. Journal of the American Statistical Association, June 2005, 680-700.

Glade, T., 2001.Landslide hazard assessment and historical landslide data - an inseparable couple? In: T. Glade, P. Albini \& F. Francès (eds.) The Use of Historical Data in Natural Hazard Assessments. Kluwer Academic Publishers: Dordrecht, 153-168.

Glade, T. 2003. Landslide occurrence as a response to land use change: a review of evidence from New Zealand. Catena 51:297-314.

Glendinning, S., Hughes, P.N., Hughes, D.A.B., Clarke, D., Smethurst, J., Powrie, W., Dixon, N., Dijkstra, T.A., Toll, D.G. \& Mendes J. 2008. Biological and engineering impacts of climate on slopes - Learning from full-scale. Proceedings 10th International Symposium on Landslides and Engineered Slopes, Xi'an, China, July 2008.

Glendinning, S., Mohammed R., Hughes, H. \& Davies O. 2006. Biological and engineering impacts of climate on slopes (BIONICS): The first 18 months. In: Engineering geology for tomorrow's cities. Procs. 10th IAEG International Congress, United Kingdom, paper 348, theme 2

Greeuw, S.C.H., van Asselt, M.B.A., Grosskurth, J., Storms, C.A.M.H., Rijkens-Klomp, N., Rothman, D.S. \& Rotmans J. 2000. An assessment of recent European and global scenario studies and models. Experts' corner report. Prospects and scenarios No 4.

Grossmann, D.A. 2003. Warming up to a not-so-radical idea: tort-based climate change litigation. Columbia Journal of Environmental Law, 28 1, 1-62

Guzetti, F., Carrara A., Cardinali, M. \& Reichenbach, P. 1999. Landslide hazard evaluation: a review of current techniques and their application in a multi-scale study, Central Italy. Geomorphology 31, $181-216$ 
Dijkstra, T.A. \& Dixon, N. (2010). Climate change and slope stability: Challenges and approaches. Quarterly Journal of Engineering Geology and Hydrogeology, 43, 4, 371-385.

Hall, J., Dawson, R., Manning, L., Walkden, M., Dickson, M. \& Sayers P. 2006. Managing changing risks to infrastructure systems. Proceedings of ICE, Civil Engineering 159, 21-27, Paper 14814.

Hanenberg, W.C. 1991. Observation and analysis of pore pressure fluctuations in a thin colluvium landslide complex near Cincinnati, Ohio. Engineering Geology 31, 159-184.

Hughes, P.N., Glendinning, S., Mendes, J., Parkin, G., Toll, D.G., Gallipoli, D., \& Miller, P. 2009. Fullscale testing to assess climate effects on embankments. Procs. Institution of Civil Engineers, Engineering Sustainability, 162, 2, 67-80

Hughes, D, Sivakumar, V, Glynn, G \& Clarke, D. 2007. A Case Study: Delayed Failure of a Deep Cutting in Lodgement Till. Journal of Geotechnical Engineering, ICE, 160 4, 193-202

Hulme, M., Jenkins, G.J., Lu, X., Turnpenny, J.R., Mitchell, T.D., Jones, R.G., Lowe, J., Murphy, J.M., Hassell, D., Boorman, P., McDonald, R. \& Hill S. 2002. Climate Change Scenarios for the United Kingdom: The UKCIP02 Scientific Report. Tyndall Centre for Climate Change Research, School of Environmental Sciences, University of East Anglia, Norwich, UK. 120pp.

Ibsen, M.L. \& Brunsden, D. 1996. The nature, use and problems of historical archives for the temporal occurrence of landslides with specific reference to the south coast of Britain, Ventnor, Isle of Wight. Geomorphology, 15, 241-258

IPCC, 2001. Climate change 2001. The Scientific Basis. Summary for Policy Makers. Cambridge University Press, Cambridge. 98pp.

Iverson, R.M. \& Major J.J. 1987. Rainfall groundwater flow and seasonal movement at Minor Creek landslide, Northwestern California: Physical interpretations of empirical relations. Geol. Soc. Am. Bull. 99, 579-594.

Iverson, R.M. 2000. Landslide triggering by rain infiltration. Water Resources Research, 36,7, 18971910.

Jackson, I. (editor) 2004. Britain Beneath Our Feet. An atlas of digital information on Britain's land quality, underground hazards, resources and geology. Keyworth Nottingham: British Geological Survey Occasional Publication No.4.

Jenkins, G.J., Perry, M.C. \& Prior M.J.O. 2009. The climate of the United Kingdom and recent trends. Met Office Hadley Centre, Exeter, UK. 121pp.

Jones, P. D., Kilsby, C. G., Harpham, C., Glenis, V., Burton, A. (2009), UK Climate Projections science report: Projections of future daily climate for the UK from the Weather Generator. University of Newcastle, UK, 48p.

Johnson, K.A. \& Sitar N. 1990. Hydrologic conditions leading to debris-flow initiation. Canadian Geotechnical Journal 27, 789-801. 
Dijkstra, T.A. \& Dixon, N. (2010). Climate change and slope stability: Challenges and approaches. Quarterly Journal of Engineering Geology and Hydrogeology, 43, 4, 371-385.

Kayane, I. \& Kaihotsu, I. 1988. Some experimental results concerning rapid water table response to surface phenomena. Journal of Hydrology 102, 215- 234.

Kilsby C.G. , Jones, P.D., Burton, A., Ford, A.C., Fowler, H.J., Harpham, C., James, P. , Smith, A. \& Wilby, R.L.. 2007. A daily weather generator for use in climate change studies. Environmental modelling and software, 22, 1705-1719.

Lacasse, S. \& Nadim, F. 1997. Uncertainties in characterizing soil properties. Publication No. 201, Norwegian Geotechnical Institute, Olso, Norway, 49-75.

Lacasse, S., Nadim, F., Hoeg, K \& Gregersen, O. 2004. Risk assessment in geotechnical engineering: the importance of engineering judgement. Advances in geotechnical engineering: the Skepmton Conference, 2004. Thomas Telford, 2, 856-867.

Lee, E.M. \& Moore R. 2007. Ventnor Undercliff: Development of landslide scenarios and quantitative risk assessment. In: McInnes, RG, Jakeways, J, Fairbank, H and E Mathie (eds.) Landslides and climate change - challenges and solutions. Taylor Francis, 323-334

Lords Hansard 2007. Roads: Motorway Lanes Closures. Lord Bassam of Brighton in answer to a question posed by Earl Attlee. 21 Nov 2007 : Column WA84.

http://www.publications. parliament.uk/pa/ld200708/ldhansrd/text/71121w0004.htm

Malet, J.-P., van Asch, Th.W.J., van Beek, R. \& Maquaire, O. 2005. Forecasting the behaviour of complex landslides with a spatially distributed hydrological model. Natural hazards and Earth System Science, 5, 71-85.

Manning L.J., Hall J.W., Kilsby C.G., Glendinning S. \& Anderson M.G. 2008. Spatial analysis of the reliability of transport networks subject to rainfall-induced landslides. Hydrological Processes. Published online by Wiley InterScience (www.interscience.wiley.com), DOI: 10.1002/hyp.6927

Matsukura, Y. 1996. The role of the degree of weathering and groundwater fluctuation in landslide movement in a colluvium of weathered hornblende-gabbro. Catena 27, 63-78.

McInnes, RG 2006. Responding to the risks from climate change in coastal zones - A good Practice Guide. Centre for the Coastal Environment, Isle of Wight Council. 84 p.

Metcalf, G., Jenkinson \& Johnstone, K. 2009. A changing climate for business. Revised edition. UKCIP, Oxford, 20p.

Moore, R, Turner, M.D., Palmer, M. \& Carey, J.M. 2007a. The Ventnor Undercliff: a new ground model and implications for climate induced landslide behaviour and risk. In: Mclnnes, R, Jakeways, J., Fairbank, H. and Mathie, E. (eds.) Landslides and climate change - challenges and solutions. Proceedings of the International Conference on Landslides and Climate Change, Ventnor, Isle of Wight. 365 - 376

Moore, R. Carey, J.M., McInnes. R.G. \& Houghton, J.E.M. 2007b. Climate change, so what? Implications for ground movement and landslide event frequency in the Ventnor Undercliff, Isle of 
Dijkstra, T.A. \& Dixon, N. (2010). Climate change and slope stability: Challenges and approaches. Quarterly Journal of Engineering Geology and Hydrogeology, 43, 4, 371-385.

Wight. In: Mclnnes, R, Jakeways, J., Fairbank, H. and Mathie, E. (eds.) Landslides and climate change - challenges and solutions. Proceedings of the International Conference on Landslides and Climate Change, Ventnor, Isle of Wight. 335 - 344

Morgenstern, N.R. \& Martin, C.D. 2008. Landslides: seeing the ground. In: Chen, Z, Zhang, J.M., Li, Z.K., Wu, F.Q. and Ho,K (Eds.) Landslides and engineered slopes: from past to the future. Procs. Tenth Int. Symp on Landslides and Engineered Slopes. Xi'an, China, 1, 3-24.

Murphy, J.M., Sexton, D.M.H., Jenkins, G.J., Boorman, P.M., Booth, B.B.B., Brown, C.C., Clark, R.T., Collins, M., Harris, G.R., Kendon, E.J., Betts, R.A., Brown, S.J., Howard, T. P., Humphrey, K. A., McCarthy, M. P., McDonald, R. E., Stephens, A., Wallace, C., Warren, R., Wilby, R., \& Wood, R. A. 2009. UK Climate Projections Science Report: Climate change projections. Met Office Hadley Centre, Exeter, 194p.

New, M., Lopez, A., Dessai, S, \& Wilby, R.. 2007. Challenges in using probabilistic climate change information for impact assessments: an example from the water sector. Phil. Trans. R.Soc, 365, 2117-2131

O'Brien, A.S. 2007. Rehabilitation of urban railway embankments- Investigation, analysis and stabilisation. Proceedings XIV European Conference on Soil Mechanics and Geotechnical Engineering, Madrid, Sept. 2007.

O'Brien A.S., Scott, J.M. \& Loveridge F. 2007. Influence of Climate and Vegetation on Railway Embankments." Proceedings XIV European Conference on Soil Mechanics and Geotechnical Engineering, Madrid, Sept. 2007.

O'Brien, A.S., Ellis, E.A., \& Russell D. 2004. Old railway embankment clay fill - laboratory experiments, numerical modelling and field behaviour. In: R.J. Jardine, D.M. Potts, K.G. Higgins (Eds); Advances in geotechnical engineering: The Skempton Conference. Thomas Telford 2004. 911-921

Oreskes, N., 1998. Evaluation (not validation) of quantitative models. Environ. Health Perspect. 106 (suppl. 6), 1453-1460

Phipps P.J. 2003. Geomorphological assessments for transport infrastructure projects. Proceedings of the Institution of Civil Engineers, Transport 156, TR3, p.131-143

Phoon, K.K. \& Kulhanny, F.H. 1999. Characterisation of geotechnical variability. Canadian Geotechnical Journal, 36, 612-624.

Phoon, K.K. \& Kulhanny, F.H. 1999. Evaluation of geotechnical property variability. Canadian Geotechnical Journal, 36, 625-639.

Perroy, L. 2006. Impacts of climate change on institutional investors - assets and liabilities, 28p. Proceedings, $28^{\text {th }}$ International Congress of Actuaries, Paris 2006, http://www.ica2006.com/Papiers/3108/3108.pdf 
Dijkstra, T.A. \& Dixon, N. (2010). Climate change and slope stability: Challenges and approaches. Quarterly Journal of Engineering Geology and Hydrogeology, 43, 4, 371-385.

Pope, V., Brown, S., Clark, R., Collins, M., Collins, W., Dearden, C., Gunson, J., Harris, G., Jones, C., Keen, A., Lowe, J., Ringer, M., Senior, C., Sitch, S., Webb, M. \& Woodward, S. . 2007. The Met Office Hadley Centre climate modelling capability: the competing requirements for improved resolution, complexity and dealing with uncertainty. Phil. Trans. R. Soc. 365, 2635-2657.

RAIB 2008. Rail accident report. - derailment at Grayrigg, 23 February 2007. Department for Transport, Report 20/2008, v2. January 2009, 255p.

Reid, M.E. 1994. A pore pressure diffusion model for estimating landslide inducing rainfall. J. Geol. 102, 709-717.

Robinson, G. 2008. The effects of clay shrinkage on embankment movement: Implications for earthworks asset management. Report on the BGA workshop 'Maintenance of Aging Earthworks' held at the ICE on 16 January 2008. 3p.

Rouainia, M., Davies, O., O'Brien, T., \& Glendinning, S. 2009. Numerical modelling of climate effects on slope stability. Procs. Institution of Civil Engineers, Engineering Sustainability, 162, 2, 81-90.

Schmidt, M. \& Glade T. 2003. Linking global circulation model outputs to regional geomorphic models: a case study of landslide activity in New Zealand. Climate Research, 25, 135-150.

Schumm, S. A. \& Lichty R. W.1965. Time, space, and causality in geomorphology. American Journal of Science, 263, February.110-119

Schumm, S. A. 1979. Geomorphic Thresholds: The Concept and Its Applications. Transactions of the Institute of British Geographers, New Series, 4(4), 485-515.

Siddle, R.C., Ziegler, A.D., Negishi, J.N., Nik, A.R., Siewc, R., \& Turkelboom, F. 2006. Erosion processes in steep terrain-Truths, myths, and uncertainties related to forest management in Southeast Asia. Forest Ecology and Management 224; 199-225.

Simoni, A., Berti, M., Generali, M., Elmi, C. \& Ghirotti M. 2004. Preliminary result from pore pressure monitoring on an unstable clay slope. Engineering Geology, 73,117- 128.

Smethurst, J.A., Clarke, D. \& Powrie W. 2006. Seasonal changes in pore water pressure in a grasscovered cut slope in London Clay. Geotechnique 56, 8, 523-537.

Stainforth, D.A., Allen, M.R., Tredger, E.R. \& Smith, L.A.. 2007 Confidence, uncertainty and decisionsupport relevance in climate predictions. Phil. Trans. R. Soc. A, 365, 2145-2161.

Stern, N.H. 2007. The Economics of Climate Change: The Stern Review. Great Britain. Treasury, Cambridge University Press, 692 pages

Take, W. \& Bolton, M.D. 2004. Identification of seasonal slope behaviour mechanisms from centrifuge case studies. In: Jardine, R.J., Potts, D.M., Higgins, K.G. (eds.) Proceedings of the Skempton conference: Advances in geotechnical engineering. Institution of Civil Engineers, 2, 992-1004 
Dijkstra, T.A. \& Dixon, N. (2010). Climate change and slope stability: Challenges and approaches. Quarterly Journal of Engineering Geology and Hydrogeology, 43, 4, 371-385.

Torres, R., Dietrich, W.E., Montgomery, D.R., Anderson, S.P. \& Loague K. 1998. Unsaturated zone processes and the hydrologic response of a steep un-channelled catchment. Water Resources Research 34 (8), 1865- 1879.

UKCIP/EPSRC 2003. Building knowledge for a changing climate - the impacts of climate change on the built environment. 24p.

http://www.ukcip.org.uk/images/stories/Pub_pdfs/Built\%20Environment.pdf

Van Asch, Th.W.J., Hendriks, M.R., Hessel, R. \& Rappange F.E. 1996. Hydrological triggering conditions of landslides in varved clays in the French Alps. Eng. Geol. 42, 239-251.

Van Asch, Th.W.J., Buma, J. \&Van Beek L.P.H. 1999. A view on some hydrological triggering systems in landslides. Geomorphology 30, p.25-32

Van Beek, L.P.H. 2002. Assessment of the influence of changes in land use and climate on landslide activity in a Mediterranean environment. Netherlands Geographical Studies NGS294, 363p.

Van Beek, L.P.H. \& Van Asch, Th.W.J. 2004. Regional assessment of the effects of land-use change on landslide hazard by means of physically based modelling. Natural Hazards 31: 289-304

Van Asch, Th.W.J., Malet, J.-P., van Beek, L.P.H. \& Amitrano, D.2007. Techniques, issues and advances in numerical modelling of landslide hazard. Bull. Soc. Geol. Fr. 178, 2, 65-88

Vaughan, P.R., Kovacevic, N., \& Ridley A.M. 2002. The influence of climate and climate change on the stability of embankment dam slopes. In: Tedd, P (ed.) Reservoirs in a changing world. Procs. $12^{\text {th }}$ Conf. British Dam Soc. 353-366.

Walsh, C.L., Hall, J.W., Street, R.B., Blanksby, J., Cassar, M., Ekins, P., Glendinning, S., Goodess, C., Handley, J., Noland, R. \& Watson, S.J. 2007. Building Knowledge for a Changing Climate: collaborative research to understand the impacts of climate change on infrastructure, the built environment and utilities, and to enable sustainable adaptation solutions. Newcastle University, March 2007

Walstra, J, Chandler, J.H., Dixon, N. \& Dijkstra T.A. 2007. Aerial photography and digital photogrammetry for landslide monitoring. In: Mapping hazardous terrain using remote sensing. Geological Society, London, Special Publications, 283; 53-63;

Walstra, J, Dixon, N., and Chandler J.H. 2007. Historical aerial photographs for landslide assessment: two case histories. Quarterly Journal of Engineering Geology \& Hydrogeology, 40(4); 315-332

Wasowski, J. 1998 Understanding rainfall-landslide relationships in man-modified environments: a case-history from Caramanico Terme, Italy. Environmental Geology 35(2-3); 197-209

Westaway, R. 2008. Warmest years in the UK and globally - 2007 update. UKCIP briefing notes: www.ukcip.org.uk 
Dijkstra, T.A. \& Dixon, N. (2010). Climate change and slope stability: Challenges and approaches. Quarterly Journal of Engineering Geology and Hydrogeology, 43, 4, 371-385.

Wilks, D.S. \& Wilby, R.L. 1999. The weather generation game: a review of stochastic weather models. Prog. in Phys. Geog., 23, 329-357.

Willows, R.I. \& Connell, R.K. (Eds.). (2003). Climate adaptation: Risk, uncertainty and decisionmaking. UKCIP Technical Report. UKCIP, Oxford. 166p.

Winter, M.G., Shackman, L. \& Macgregor F. 2007. Landslide management and mitigation in the Scottish Road Network. In: McInnes, RG, Jakeways, J, Fairbank, H and E Mathie (eds.) Landslides and Climate Change - Challenges and Solutions. Proceedings of the International Conference on Landslides and Climate Change, Ventnor, Isle of Wight, UK, p249-258.

Zhao, H.B. 2008. Slope reliability analysis using a support vector machine. Computers and geotechnics, 35, 459-467. 
Dijkstra, T.A. \& Dixon, N. (2010). Climate change and slope stability: Challenges and approaches. Quarterly Journal of Engineering Geology and Hydrogeology, 43, 4, 371-385.

\section{Tables}

Table 1. Highlights of recent climate trends for the United Kingdom (from Jenkins et al. 2009).

(IPCC terminology to express likelihoods: very likely $=>90 \%$ probability, likely $=>66 \%$ probability)

Warming of the global climate system is unequivocal, with global average temperatures having risen by nearly $0.8^{\circ} \mathrm{C}$ since the late 19 th century, and rising at about $0.2^{\circ} \mathrm{C} /$ decade over the past 25 years.

It is very likely* that man-made greenhouse gas emissions caused most of the observed temperature rise since the mid 20th century.

Global sea-level rise has accelerated between mid-19th century and mid-20 ${ }^{\text {th }}$ century, and is now about $3 \mathrm{~mm}$ per year. It is likely* that human activities have contributed between a quarter and a half of the rise in the last half of the 20th century.

Central England Temperature has risen by about a degree Celsius since the 1970s, with 2006 being the warmest on record. It is likely that there has been a significant influence from human activity on the recent warming.

Temperatures in Scotland and Northern Ireland have risen by about $0.8^{\circ} \mathrm{C}$ since about 1980 , but this rise has not been attributed to specific causes.

Annual mean precipitation over England and Wales has not changed significantly since records began in 1766 . Seasonal rainfall is highly variable, but appears to have decreased in summer and increased in winter, although with little change in the latter over the last 50 years.

All regions of the UK have experienced an increase over the past 45 years in the contribution to winter rainfall from heavy precipitation events; in summer all regions except NE England and N Scotland show decreases.

There has been considerable variability in the North Atlantic Oscillation, but with no significant trend over the past few decades.

Severe windstorms around the UK have become more frequent in the past few decades, though not above that seen in the 1920 s.

Sea-surface temperatures around the UK coast have risen over the past three decades by about $0.7^{\circ} \mathrm{C}$.

Sea level around the UK rose by about $1 \mathrm{~mm} / \mathrm{yr}$ in the 20th century, corrected for land movement. The rate for the 1990s and 2000s has been higher than this. 
Dijkstra, T.A. \& Dixon, N. (2010). Climate change and slope stability: Challenges and approaches. Quarterly Journal of Engineering Geology and Hydrogeology, 43, 4, 371-385.

Table 2. Highlights of the summer, winter and annual mean changes forecasted for the 2080s (relative to a 1961-1990 baseline) under the Medium emissions scenario. These are central estimates of change (50\% probability level). In brackets, values are shown that indicate a minimum value that is very likely to be exceeded ( $10 \%$ probability level) and a maximum value that is very likely not going to be exceeded (90\% probability level; from Murphy et al. 2009)

\begin{tabular}{|c|c|c|}
\hline \multirow{3}{*}{$\begin{array}{l}\text { temperature } \\
\text { all areas of } \\
\text { the UK will get } \\
\text { warmer, more } \\
\text { so in summer } \\
\text { than in winter }\end{array}$} & $\begin{array}{l}\text { summer mean } \\
\text { temperature }\end{array}$ & $\begin{array}{l}\left.\text { southern England - increases are up to } 4.2^{\circ} \mathrm{C}\left(2.2 \text { to } 6.8^{\circ} \mathrm{C}\right)\right) \\
\left.\text { Scottish islands - increases are to just over } 2.5^{\circ} \mathrm{C}\left(1.2 \text { to } 4.1^{\circ} \mathrm{C}\right)\right)\end{array}$ \\
\hline & $\begin{array}{l}\text { mean daily maximum } \\
\text { temperatures }\end{array}$ & $\begin{array}{l}\text { summer average: } \\
\text { southern Britain - increases are up to } 5.4^{\circ} \mathrm{C}\left(2.2 \text { to } 9.5^{\circ} \mathrm{C}\right) \\
\text { northern Britain - increases are up to } 2.8^{\circ} \mathrm{C}\left(1 \text { to } 5^{\circ} \mathrm{C}\right) \\
\text { winter average: } \\
\text { increases range from } 1.5^{\circ} \mathrm{C}\left(0.7 \text { to } 2.7^{\circ} \mathrm{C}\right) \text { to } 2.5^{\circ} \mathrm{C}\left(1.3 \text { to } 4.4^{\circ} \mathrm{C}\right)\end{array}$ \\
\hline & $\begin{array}{l}\text { mean daily minimum } \\
\text { temperature }\end{array}$ & $\begin{array}{l}\text { summer average: } \\
\text { southern Britain - increases are up to } 4.1^{\circ} \mathrm{C}\left(2.0 \text { to } 7.1^{\circ} \mathrm{C}\right) \\
\text { northern Britain - increases are up to } 2.7^{\circ} \mathrm{C}\left(1.3 \text { to } 4.5^{\circ} \mathrm{C}\right) \\
\text { winter average: } \\
\text { increases range from } 2.1^{\circ} \mathrm{C}\left(0.6 \text { to } 3.7^{\circ} \mathrm{C}\right) \text { to } 3.5^{\circ} \mathrm{C}\left(1.5 \text { to } 5.9^{\circ} \mathrm{C}\right)\end{array}$ \\
\hline \multirow[t]{4}{*}{ precipitation } & annual precipitation & $\begin{array}{l}\text { very little change everywhere at the } 50 \% \text { probability level. Changes } \\
\text { range from }-16 \% \text { in some places at the } 10 \% \text { probability level, to } \\
+14 \% \text { in some places at the } 90 \% \text { probability level, with no simple } \\
\text { pattern. }\end{array}$ \\
\hline & winter precipitation & $\begin{array}{l}\text { western Britain }- \text { increases up to }+33 \%(+9 \text { to }+70 \%) \\
\text { Scottish highlands }- \text { decreases of a few percent }(-11 \text { to }+7 \%)\end{array}$ \\
\hline & summer precipitation & $\begin{array}{l}\text { far south of England - decreases to about }-40 \%(-65 \text { to }-6 \%) \\
\text { northern Scotland - changes remain close to zero }(-8 \text { to }+10 \%)\end{array}$ \\
\hline & wettest days & $\begin{array}{l}\text { summer: } \\
\text { southern England - decreases to }-12 \%(-38 \text { to }+9 \%) \\
\text { Scotland - increases to }+12 \%(-1 \text { to }+51 \%) \\
\text { winter: } \\
\text { Scotland - very little change forecasted }(-12 \text { to }+13 \%) \\
\text { parts of England - changes can reach up to }+25 \%(+7 \text { to }+56 \%)\end{array}$ \\
\hline soil moisture & \multicolumn{2}{|c|}{$\begin{array}{l}\text { Although probabilistic projections of soil moisture variations have not been possible due to the } \\
\text { differences between models in the way these define soil moisture, significant reductions in soil } \\
\text { moisture for end-of-summer conditions are expected across the UK, with the largest reductions } \\
\text { - between } 20 \% \text { and } 50 \% \text { by the } 2080 \text { s - in the south and east (Murphy et al. } 2009 \text {, and Hulme } \\
\text { et al. } 2002 \text { ). }\end{array}$} \\
\hline
\end{tabular}


Dijkstra, T.A. \& Dixon, N. (2010). Climate change and slope stability: Challenges and approaches. Quarterly Journal of Engineering Geology and Hydrogeology, 43, 4, 371-385.

\section{Figures}

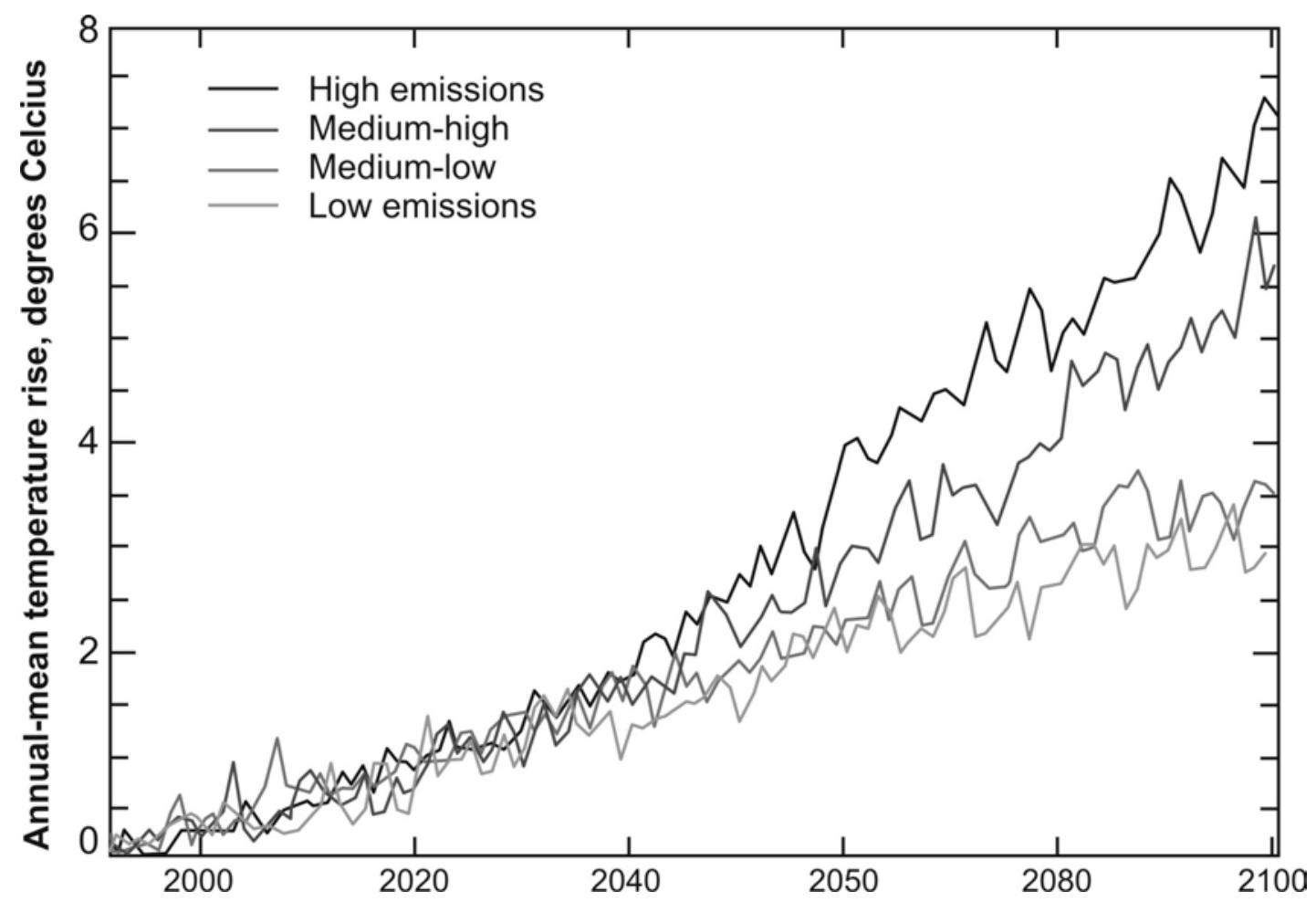

Figure 1. Examples of four different emission scenarios outcomes on the modelling of annual-mean temperature rise relevant to the 1961-1990 average (sources CDIAC, IPCC, Hadley Centre; redrawn from Jenkins 2006, pers. comm.). 
Dijkstra, T.A. \& Dixon, N. (2010). Climate change and slope stability: Challenges and approaches. Quarterly Journal of Engineering Geology and Hydrogeology, 43, 4, 371-385.

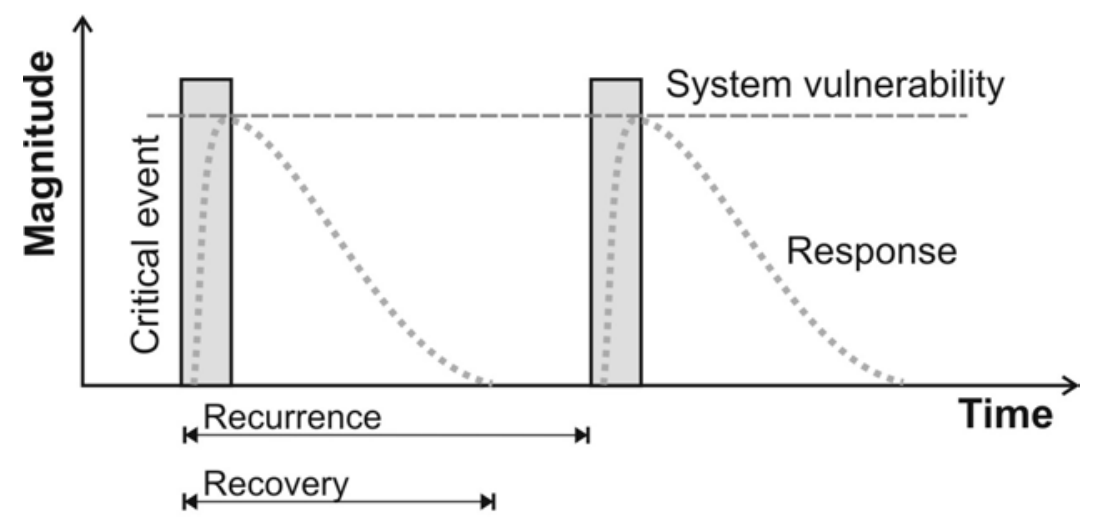

(A)

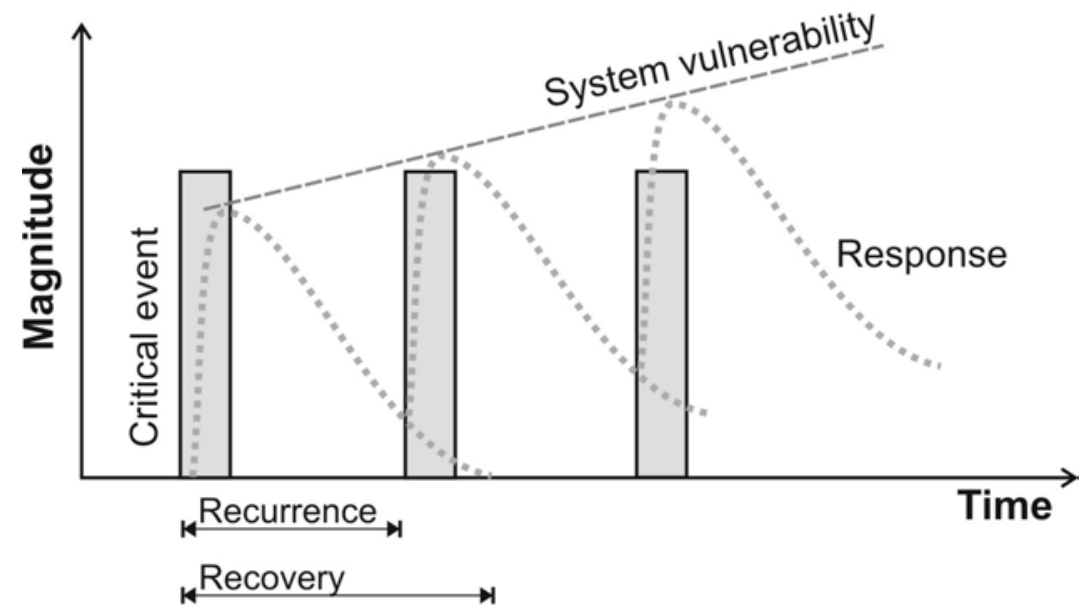

(B)

Figure 2. An imbalance between the recurrence of critical events (e.g. those resulting in the loss of shear strength along slip surfaces) and the recovery time (e.g. the time required for dissipation of pore pressures) forms one of the mechanisms that can determine the long term vulnerability of a slope system. In (a) there is sufficient time available between each critical event for the slope to regain stability. However, if these events occur more frequently (b), the system itself may become unstable and slope movements may ensue. 
Dijkstra, T.A. \& Dixon, N. (2010). Climate change and slope stability: Challenges and approaches. Quarterly Journal of Engineering Geology and Hydrogeology, 43, 4, 371-385.
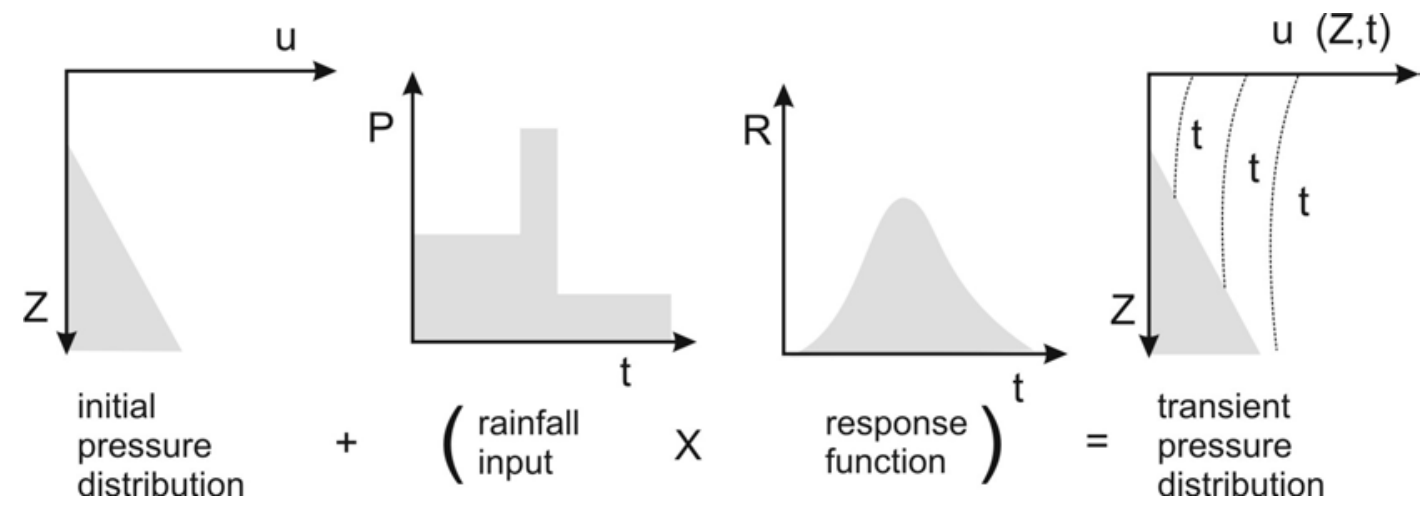

Figure 3. A conceptual approach illustrating the determination of transient pore pressure (pore pressure $u$ as a function of soil depth $Z$ and time $t$ ), using an initial pressure distribution of pore pressure $(\mathrm{U})$ against depth $(\mathrm{Z})$, and a rainfall input function (here simplified as precipitation $(\mathrm{P})$ against time (t)) that is combined with an appropriate response (R) over time (after Iverson, 2000). An example of the importance of $Z$ when applied to hill slopes is shown in Figure 4. 
Dijkstra, T.A. \& Dixon, N. (2010). Climate change and slope stability: Challenges and approaches. Quarterly Journal of Engineering Geology and Hydrogeology, 43, 4, 371-385.

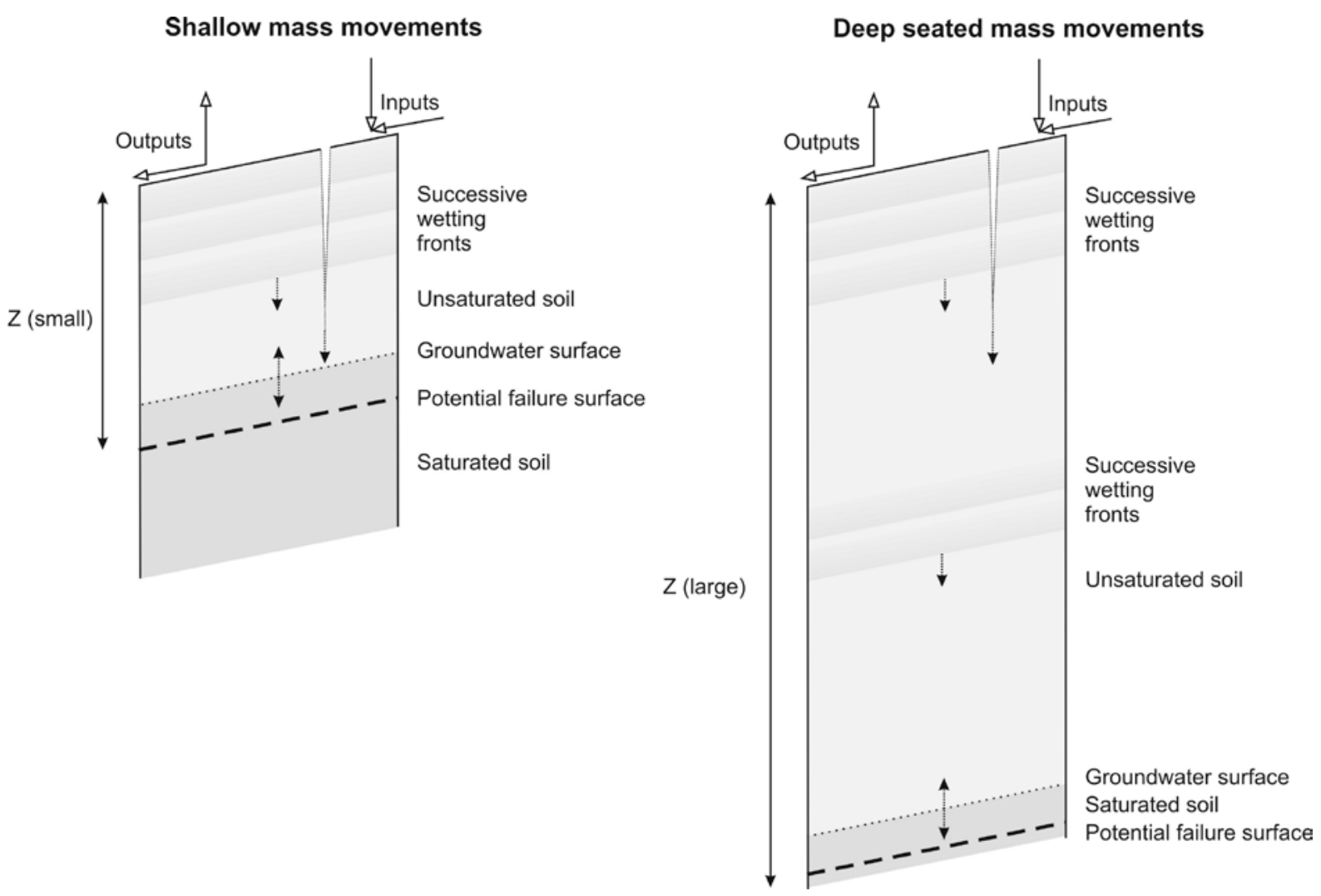

Figure 4. Conceptual models illustrating the effects of multiple rainfall events on the triggering of slope movements for both shallow and deep-seated potential failure surfaces. The complex set of inputs comprises variables such as precipitation and infiltration, while the equally complex set of outputs include variables such as evapotranspirative losses. Naturally, these inputs and outputs are not just limited to the slope's surface - they are also relevant to the soil column where inputs from upslope and outputs to the lower slope must be considered to fully appreciate the water balance. The schematic representation of a desiccation crack illustrates the potential contributions these cracks can have on triggering pore pressure variations at potential failure surfaces in shallow mass movement environments. Where potential failure surfaces are situated at a greater depth both the effects of crack systems and individual rainfall events are less likely to be significant. 